\title{
IAMJ
}

INTERNATIONAL

AYURVEDIC

MEDICAL JOURNAL

do) $\partial \subseteq$

\section{COMPARATIVE STUDY OF EFFICACY OF SHATAVARI GHRUTA ANJANA AND ERANDA TAILA ANJANA IN THE MANAGEMENT OF VISUAL DISPLAY TERMINAL SYNDROME}

\section{$\underline{\text { Vijay Dubey }}^{1}$, S.S. Salvi ${ }^{2}$}

${ }^{1}$ Assistant professor, Dept. of Shalakya Tantra, Sri sai institute of Ayurvedic Research and medicine Bhopal (M.P.), India

${ }^{2}$ Professor, H.O.D., Dept. of Shalakya Tantra, Tilak Ayurved Mahavidyalaya, Pune (Maharashtra), India

Corresponding Author: drvijaydubey1@gmail.com

https://doi.org/10.46607/iamj0609092021

(Published Online: September 2021)

Open Access

(C) International Ayurvedic Medical Journal, India 2021

Article Received: 23/08//2021 - Peer Reviewed: 03/09/2021 - Accepted for Publication: 04/09/2021

\section{Check for updates}

\section{ABSTRACT}

This study was conducted to evaluate the efficacy of Shatavari ghutra Anjana and Eranda taila anjana in the management of the visual display syndrome. For this work patients attending the netraroga (ophthalmology) OPD at the hospital attached to Tilak Ayurveda Mahavidyalaya, Pune (Maharashtra) was selected based on the inclusion and exclusion criteria of the study. Ethical clearance was accredited by the institutional ethical committee of the institute and written consent from all the selected patients was taken before the treatment. The selected patients were randomly divided into two groups. Group A was given Shatavari ghruta anjana in each eye one time a day for one month and group B was given Eranda taila anjana in each eye one time a day for one month. The clinical data collected and compiled from this clinical trial was sorted out processed by implying various statistical methods and it was found that Group A showed comparatively better results in redness of eyes and eye irritation.

Keywords: Shatavari ghruta anjana, Eranda taila anjana, visual display syndrome. 


\section{INTRODUCTION}

Vocational and non-vocational use of computers and digital electronic devices has increased with development in the electronic industry and easy availability of devices. Due to long working hours in front of the computer and other short screens, related vision and other ophthalmic symptoms like eye strain, dry eye, eye irritation, blurred vision, headache, and redness may develop. These have been collectively called Computer Vision Display Terminal Syndrome (VDTS) or Computer Vision Syndrome (CVS). Images on computer screen contrast are not sharp; edges of characters are not well defined, so eyes have difficulty in focusing causing strain on ciliary muscles of an eye leading to symptoms of VDTS. Prolong maintenance of the same posture and even wrong posture puts strain on neck muscles and cervical spine leading to neck pain and headache. According to the National Institute of Safety and health, CVS affects about $90 \%$ of the population who spent three or more hours a day on the computer and digital devices ${ }^{1}$. Asthenopic symptoms in the eyes are responsible for much of the morbidity in CVS. In modern medical science, artificial tear drops are usually recommended but they give only temporary and symptomatic relief. The present study was conducted on patients reporting in netraroga OPD of Tilak Ayurveda Mahavidyalaya, Pune (Maharashtra). Ethical clearance was accredited by the institutional ethical committee of the institute (Ref no. RSTH/PG/IEC/1269/2019). The selected patients were randomly divided into two groups. Group A $(n=30)$ was given Shatavari ghruta anjana in each eye one time a day for one month and group B $(n=30)$ was given Eranda taila anjana in each eye one time a day for one month. The drugs were prepared in the pharmacy of the institution for which a standardization certificate was obtained from Savitribai Phule Pune. University

\section{MATERIALS AND METHOD-}

The selected patients were randomly divided into 2 groups with the following drug schedule-

- Group A (n=30)- Shtavari ghruta anjana in each eye one time a day for one month.

- Group A (n=30)- Eranda taila anjana in each eye one time a day for one month.

\section{PROCEDURE FOR APPLYING ANJANA ${ }^{2}$}

- Vartma (eyelid) should be held firmly with the left hand so that the patient cannot blink.

- Hold the adhovartma and apply the anjana from Kaneenaka (inner canthus) to Apanga pradesha (outer canthus) with a finger.

- After application of anjana the eyes should remain close, and the patient is asked to mildly rotate the eyeball inside the lids.

- Eyes should not be opened and close.

- Eyes should not be washed immediately after the application of anjana.

DOSAGE AND DURATION (LOCAL APPLICATION OF ANJANA)

- Dosage : $0.04 \mathrm{ml}$

- Time : Evening

- Duration :1 Month

\section{STANDARDIZATION OF SHATAVARI GHRUTA AND ERAND TAILA-}

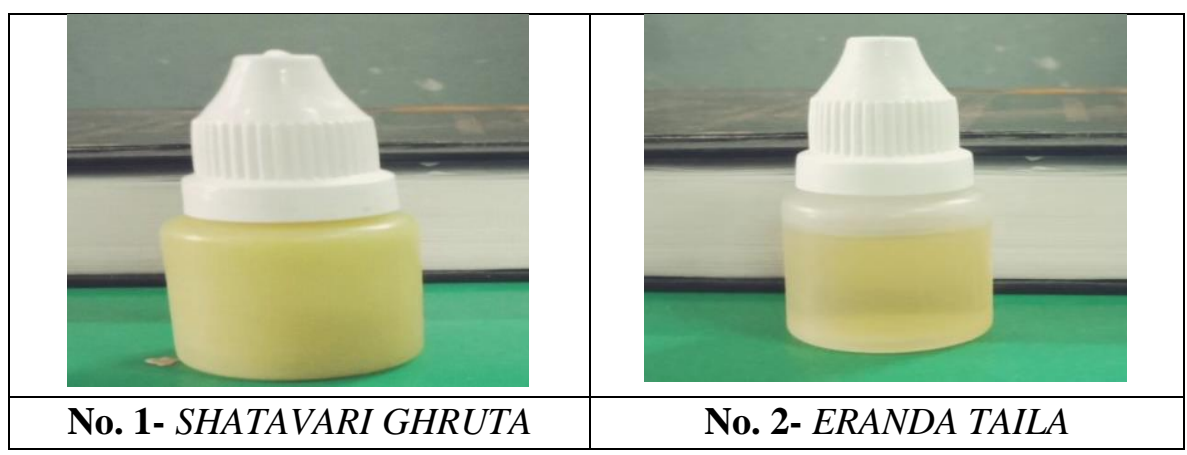


TABLE 1: SHOWING ORGANOLEPTIC PROPERTIES OF SHATAVARI GHRUTA

\begin{tabular}{|l|l|l|}
\hline S.NO. & PARAMETERS & SHATAVARI GHRUTA \\
\hline 1 & Colour & Whitish brown \\
\hline 2 & Odour & Characteristic \\
\hline 3 & Texture & Smooth, greasy \\
\hline 4 & Taste & Characteristic \\
\hline
\end{tabular}

TABLE 2: SHOWING PHYTOCHEMICAL EVALUATION OF SHATAVARI GHRUTA

\begin{tabular}{|l|l|l|}
\hline S.NO. & PARAMETERS & SHATAVARI GHRUTA \\
\hline 1 & Ph value & 6.95 \\
\hline 2 & Pugnacity & $0.901 \mathrm{~g} / \mathrm{cm}^{3}$ \\
\hline 3 & Refractive index & 1.4532 \\
\hline 4 & Iodine value & $32.560 \mathrm{mg} / \mathrm{g}$ \\
\hline 5 & Saponification value & $224 / \mathrm{mg} / \mathrm{g}$ \\
\hline 6 & Acid value & $1.811 \mathrm{PaS}$ \\
\hline
\end{tabular}

- ERANDA TAILA

TABLE 3: SHOWING ORGANOLEPTIC PROPERTIES OF ERANDA TAILA

\begin{tabular}{|l|l|l|}
\hline S.NO. & PARAMETERS & ERANDA TAILA \\
\hline 1 & Colour & Pale white \\
\hline 2 & Odour & Characteristic \\
\hline 3 & Texture & Viscous oily \\
\hline 4 & Taste & Bland \\
\hline
\end{tabular}

TABLE 4: SHOWING PHYTOCHEMICAL EVALUATION OF ERANDA TAILA

\begin{tabular}{|l|l|l|}
\hline S.No. & PARAMETERS & ERANDA TAILA \\
\hline 1 & Ph & 6.1 \\
\hline 2 & Viscosity at $300 \mathrm{~K}$ & $0.652 \mathrm{PaS}$ \\
\hline 3 & Refractive index & 1.48 \\
\hline 4 & Saponification value & $182.9 \mathrm{mg} / \mathrm{g}$ \\
\hline 5 & Acid value & $0.88 \mathrm{mg} / \mathrm{g}$ \\
\hline 6 & Specific gravity & $0.988 \mathrm{mg} / \mathrm{g}$ \\
\hline 7 & Iodine value & $84.5 \mathrm{I}_{2 / 100 ~}$ \\
\hline 8 & Density & $965 \mathrm{~kg} / \mathrm{m}^{3}$ \\
\hline 9 & Boiling point & $312^{\circ} \mathrm{C}$ \\
\hline
\end{tabular}

\section{SELECTION CRITERIA-}

\section{Inclusion criteria}

1. Patients willing for the trial.

2. Patients from the age group 18 to 70 years, both male and female.
3. Patients working on VDTS for at least 4 hours daily for a minimum of 2 years.

4. Patients suffering from at least 4 symptoms of the following - eye strain, dry eyes, eye irritation, blurred vision, headache, and redness of eyes. 


\section{Exclusion criteria -}

1. Patients not willing for trial.

2. Patients below the age of 18 and above 70 years.

3. Patients having symptoms due to direct physiological effects or any general medical condition or systemic disorder.

4. Patients having abnormal ophthalmoscope findings.

Follow-up of these patients was taken weekly for consecutive 4 weeks and these observations were subjected to analysis. At the first visit, a routine ophthalmological examination was done. The patients were explained about the ergonomic considerations concerning their workplace and asked to do the required possible changes.

The observations were recorded by gradation scale as per the Ocular Surface Disease Index (OSDI) ${ }^{3}$ for the subjective criteria as follows: -

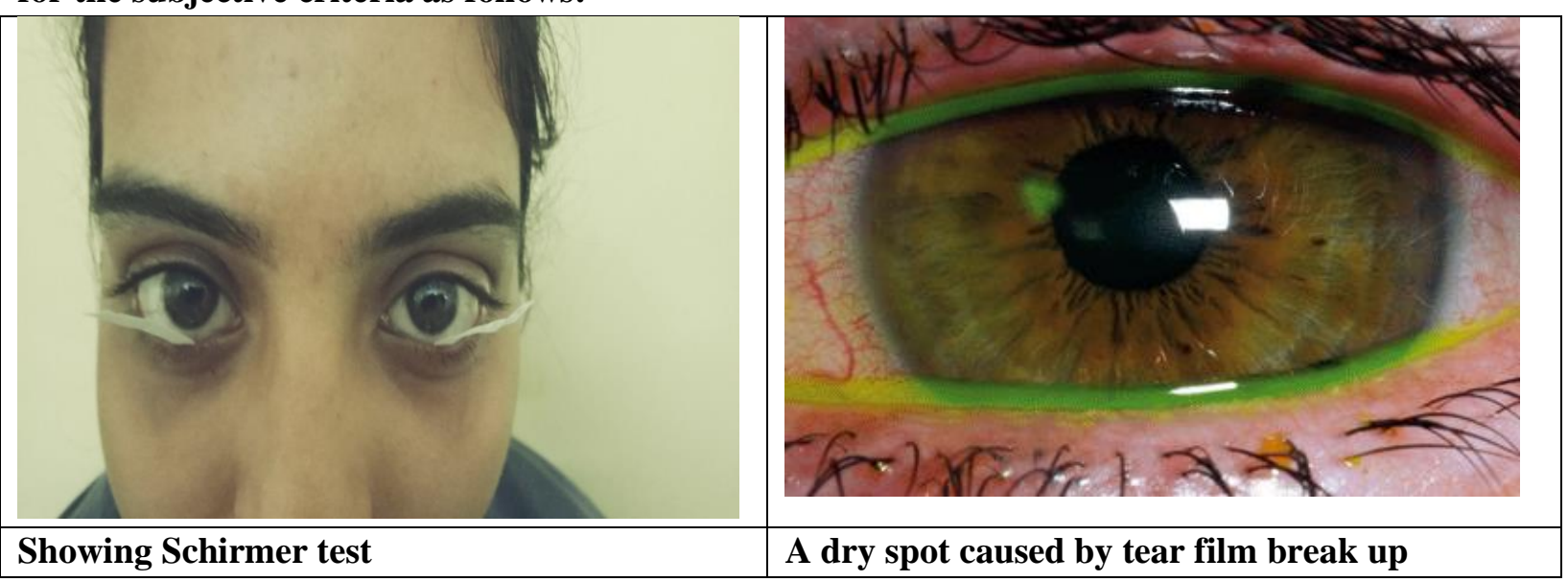

For all 6 symptoms: -

0 - Symptom occurs after working on VDTS for 4 hrs.

1 - Symptom occurs after working on VDTS for 3 hrs.

2 - Symptom occurs after working on VDTS for 2 hrs.

3 - Symptom occurs after working on VDTS for 1 hrs.

4 - Symptom occurs after working on VDTS for $1 / 2$ hrs.

Clinical examination of patients was done to evaluate the tear film by following tests ${ }^{4,5}$

1. Schirmer's test

2. Tear film break uptime

3. Slit-lamp examination

\section{OBSERVATION AND RESULTS-}

The results obtained from the clinical study were compiled and evaluated by statistical analysis.

DEMOGRAPHICAL DATA-

TABLE 5: AGE WISE DISTRIBUTION OF PATIENTS-

\begin{tabular}{|l|l|l|l|l|l|l|}
\hline \multirow{2}{*}{ AGE GROUP } & \multicolumn{3}{l}{ Group A } & Group B & \multicolumn{2}{l|}{ Total } \\
\hline & N & $\%$ & N & $\%$ & N & $\%$ \\
\hline 20-30 Years & 25 & 83.3 & 24 & 80.0 & 49 & 81.7 \\
\hline 30-40 Years & 4 & 13.3 & 5 & 16.7 & 9 & 15.0 \\
\hline 40-50 Years & 1 & 3.3 & 1 & 3.3 & 2 & 3.3 \\
\hline TOTAL & 30 & 100.0 & 30 & 100.0 & 60 & 100.0 \\
\hline
\end{tabular}


TABLE 6: GENDER WISE DISTRIBUTION OF PATIENTS-

\begin{tabular}{|l|l|l|l|l|l|l|}
\hline \multirow{2}{*}{ GENDER } & \multicolumn{3}{l|}{ Group A } & Group B & \multicolumn{2}{l|}{ Total } \\
\cline { 2 - 7 } & $\mathrm{N}$ & $\%$ & $\mathrm{~N}$ & $\%$ & $\mathrm{~N}$ & $\%$ \\
\hline Male & 23 & 76.7 & 17 & 56.7 & 40 & 66.7 \\
\hline Female & 7 & 23.3 & 13 & 43.3 & 20 & 33.3 \\
\hline TOTAL & 30 & 100.0 & 30 & 100.0 & 60 & 100.0 \\
\hline
\end{tabular}

TABLE 7: RELIGION WISE DISTRIBUTION OF PATIENTS-

\begin{tabular}{|l|l|l|l|l|l|l|}
\hline \multirow{2}{*}{ RELIGION } & \multicolumn{2}{|c|}{ Group A } & Group B & \multicolumn{2}{l|}{ Total } \\
\cline { 2 - 7 } & N & $\%$ & N & $\%$ & N & $\%$ \\
\hline Buddhist & 2 & 6.7 & 2 & 6.7 & 4 & 6.7 \\
\hline Hindu & 26 & 86.7 & 26 & 86.7 & 52 & 86.7 \\
\hline Muslim & 2 & 6.7 & 2 & 6.7 & 4 & 6.7 \\
\hline TOTAL & 30 & 100.0 & 30 & 100.0 & 60 & 100.0 \\
\hline
\end{tabular}

TABLE 8: OCCUPATION WISE DISTRIBUTION OF PATIENTS-

\begin{tabular}{|l|l|l|l|l|l|l|}
\hline \multirow{2}{*}{ OCCUPATION } & \multicolumn{2}{l|}{ Group A } & \multicolumn{2}{l|}{ Group B } & \multicolumn{2}{l|}{ Total } \\
\cline { 2 - 7 } & $\mathrm{N}$ & $\%$ & $\mathrm{~N}$ & $\%$ & $\mathrm{~N}$ & $\%$ \\
\hline Business & 0 & 0.0 & 1 & 3.3 & 1 & 1.7 \\
\hline Housewife & 1 & 3.3 & 0 & 0.0 & 1 & 1.7 \\
\hline Job & 2 & 6.7 & 2 & 6.7 & 4 & 6.7 \\
\hline Student & 27 & 90.0 & 27 & 90.0 & 54 & 90.0 \\
\hline TOTAL & 30 & 100.0 & 30 & 100.0 & 60 & 100.0 \\
\hline
\end{tabular}

TABLE 9: MARITAL STATUS WISE DISTRIBUTION OF PATIENTS-

\begin{tabular}{|l|l|l|l|l|l|l|l|}
\hline \multirow{2}{*}{ MARITAL STATUS } & Group A & Group B & \multicolumn{2}{l|}{ Total } \\
\cline { 2 - 8 } & $\mathrm{N}$ & $\%$ & $\mathrm{~N}$ & $\%$ & $\mathrm{~N}$ & $\%$ \\
\hline Married & 29 & 96.7 & 29 & 96.7 & 58 & 96.7 \\
\hline Unmarried & 1 & 3.3 & 1 & 3.3 & 2 & 3.3 \\
\hline TOTAL & 30 & 100.0 & 30 & 100.0 & 60 & 100.0 \\
\hline
\end{tabular}

TABLE 10: FAMILY HISTORY WISE DISTRIBUTION OF PATIENTS-

\begin{tabular}{|l|l|l|l|l|l|l|}
\hline \multirow{2}{*}{ FAMILY HISTORY } & \multicolumn{2}{|l|}{ Group A } & Group B & \multicolumn{2}{l|}{ Total } \\
\hline & $\mathrm{N}$ & $\%$ & $\mathrm{~N}$ & $\%$ & N & $\%$ \\
\hline No & 30 & 100.0 & 30 & 100.0 & 60 & 100.0 \\
\hline Yes & 0 & 0.0 & 0 & 0.0 & 0 & 0.0 \\
\hline TOTAL & 30 & 100.0 & 30 & 100.0 & 60 & 100.0 \\
\hline
\end{tabular}

TABLE 11: DIET WISE DISTRIBUTION OF PATIENTS-

\begin{tabular}{|l|l|l|l|l|l|l|}
\hline \multirow{2}{*}{ DIET } & \multicolumn{3}{l}{ Group A } & Group B & \multicolumn{2}{l|}{ Total } \\
\cline { 2 - 7 } & $\mathrm{N}$ & $\%$ & $\mathrm{~N}$ & $\%$ & $\mathrm{~N}$ & $\%$ \\
\hline Mixed & 18 & 60.0 & 18 & 60.0 & 36 & 60.0 \\
\hline Veg & 12 & 40.0 & 12 & 40.0 & 24 & 40.0 \\
\hline TOTAL & 30 & 100.0 & 30 & 100.0 & 60 & 100.0 \\
\hline
\end{tabular}




\section{SYMPTOMS WISE CHANGES-}

Since observations are on an ordinal scale (gradations), we have used Wilcoxon Signed Rank Test to test efficacy in Group A and Group B.

\section{EYES STRAIN-}

TABLE 12: EFFECT OF TREATMENT ON EYES STRAIN-

\begin{tabular}{|l|l|l|l|l|l|l|}
\hline EYES STRAIN & Median & Wilcoxon & Signed-Rank & P-Value & \% Effect & Result \\
\cline { 2 - 5 } & BT & AT & W & & & \\
\hline Group A & 3 & 0 & $-4.824^{\mathrm{a}}$ & 0.000 & 87.9 & Significant \\
\hline Group B & 3 & 0 & $-4.830^{\mathrm{a}}$ & 0.000 & 92.6 & Significant \\
\hline
\end{tabular}

\section{DRY EYES}

TABLE 13: EFFECT OF TREATMENT ON DRY EYES-

\begin{tabular}{|l|l|l|l|l|l|l|}
\hline \multirow{2}{*}{ DRY EYES } & Median & Wilcoxon & Signed-Rank & P-Value & \% Effect & Result \\
\cline { 2 - 5 } & BT & AT & W & & & \\
\hline Group A & 3 & 0 & $-4.814^{\mathrm{a}}$ & 0.000 & 91.3 & Significant \\
\hline Group B & 3 & 0 & $-4.807^{\mathrm{a}}$ & 0.000 & 94.9 & Significant \\
\hline
\end{tabular}

3. EYS IRRITATION

TABLE 14: EFFECT OF TREATMENT ON EYE IRRITATION-

\begin{tabular}{|l|l|l|l|l|l|l|}
$\begin{array}{l}\text { EYE IRRITA- } \\
\text { TION }\end{array}$ & Median & Wilcoxon Signed-Rank W & P-Value & \% Effect & Result \\
\hline Group A & 3 & AT & & & & \\
\hline Group B & 3 & 0 & $-4.529^{\mathrm{a}}$ & 0.000 & 89.2 & Significant \\
\hline
\end{tabular}

\section{BLURRED VISION}

TABLE 15: EFFECT OF TREATMENT ON BLURRED VISION-

\begin{tabular}{|l|l|l|l|l|l|l|}
\hline \multirow{2}{*}{$\begin{array}{l}\text { BLURRED } \\
\text { VISION }\end{array}$} & \multicolumn{2}{|l|}{ Median } & Wilcoxon Signed-Rank W & P-Value & \% Effect & Result \\
\cline { 2 - 6 } & BT & AT & & & & \\
\hline Group A & 3 & 0.5 & $-4.542^{\mathrm{a}}$ & 0.000 & 71.4 & Significant \\
\hline Group B & 2 & 0 & $-4.497^{\mathrm{a}}$ & 0.000 & 81.3 & Significant \\
\hline
\end{tabular}

\section{HEADACHE}

TABLE 16: EFFECT OF TREATMENT ON HEADACHE-

\begin{tabular}{|l|l|l|l|l|l|l|}
\hline \multirow{2}{*}{ HEADACHE } & \multicolumn{2}{|l|}{ Median } & Wilcoxon Signed-Rank W & P-Value & \% Effect & Result \\
\cline { 2 - 7 } & BT & AT & & & & \\
\hline Group A & 2 & 0 & $-4.169^{\mathrm{a}}$ & 0.000 & 85.5 & Significant \\
\hline Group B & 2.5 & 0 & $-4.573^{\mathrm{a}}$ & 0.000 & 90.9 & Significant \\
\hline
\end{tabular}

\section{REDNESS OF EYES}

TABLE 17: EFFECT OF TREATMENT REDNESS OF EYES-

\begin{tabular}{|l|l|l|l|l|l|l|}
\hline \multirow{2}{*}{ REDNESS } & \multicolumn{2}{|l|}{ Median } & Wilcoxon Signed-Rank W & P-Value & \% Effect & Result \\
\cline { 2 - 5 } & BT & AT & & & & \\
\hline Group A & 1 & 0 & $-3.573^{\mathrm{a}}$ & 0.000 & 85.3 & Significant \\
\hline Group B & 2 & 0 & $-4.172^{\mathrm{a}}$ & 0.000 & 92.7 & Significant \\
\hline
\end{tabular}




\section{SHIRMER'S TEST-}

TABLE 18: EFFECT OF TREATMENT ON SCHIRMER'S TEST-

\begin{tabular}{|l|l|l|l|l|l|l|l|l|l|}
\hline SCHIRMER'S TEST & Mean & N & SD & SE & t-Value & P-Value & \% Effect & Result \\
\hline Group A & BT & 9.04 & 30 & 2.40 & 0.44 & 6.687 & 0.000 & 41.59 & Sig \\
\cline { 2 - 10 } & AT & 12.80 & 30 & 2.10 & 0.38 & & & & \\
\hline \multirow{2}{*}{ Group B } & BT & 9.20 & 30 & 2.80 & 0.51 & 5.707 & 0.000 & 30.22 & Sig \\
\cline { 2 - 10 } & AT & 11.98 & 30 & 2.40 & 0.44 & & & & \\
\hline
\end{tabular}

Since observations are quantitative, we have used paired t-test. From the above table, we can observe that PValues for Group A and Group B are less than 0.05. Hence, we conclude that the effect observed in both groups is significant.

\section{TEAR FILM BREAK UPTIME}

TABLE 19: EFFECT OF TREATMENT ON TEAR FILM BREAK UPTIME

\begin{tabular}{|l|l|l|l|l|l|l|l|l|l|}
\hline TFBUT & & Mean & N & SD & SE & t-Value & P-Value & \% Effect & Result \\
\hline Group A & BT & 8.43 & 30 & 2.40 & 0.44 & 6.327 & 0.000 & 24.79 & Sig \\
\cline { 2 - 9 } & AT & 10.52 & 30 & 2.10 & 0.38 & & & & \\
\hline \multirow{2}{*}{ Group B } & BT & 8.22 & 30 & 2.80 & 0.51 & 5.438 & 0.000 & 20.80 & Sig \\
\cline { 2 - 9 } & AT & 9.93 & 30 & 2.40 & 0.44 & & & & \\
\hline
\end{tabular}

Since observations are quantitative, we have used paired t-test. From the above table, we can observe that P-Values for Group A and Group B are less than 0.05 . Hence, we conclude that the effect observed in both groups is significant.

\section{DISCUSSION}

From the above study, it is concluded that demographically prevalence of Computer Vision Terminal Syndrome is more prevalent in the age group of 20-30 years $(81.7 \%)$, more prevalent in males as compared to females in both study groups $(66.7 \%)$. Higher prevalence was seen in the Hindu population as understood due to the higher population group in the study. Occupation wise disease was more prevalent amongst students due to excessive use of electronic gadgets.

The symptoms of Computer Vision Display Terminal Syndrome (VDTS) are eyes strain, dryness of eyes, eye irritation, blurred vision, headache, and redness of eyes. On critical analysis of symptoms on Tridosha theory of Ayurveda, it seems to be Vata-pitta origin in nature.

In this study, it was statistically analysed that Shatavari Ghruta and Eranda Taila have a significant effect on all the parameters in VDTS (P-Values for Group A and Group B are less than 0.05). Shatavari ghruta showed comparatively better results in redness of eyes and eye irritation, there was no significant difference between symptoms of eyes strain, dryness of eyes and blurred vision. Shatavari (Asparagus racemosus) is said to be Chakshushya (good for eyes), which pacifies Vata-pitta and sheeta virya in nature ${ }^{6}$. Cow's ghruta is also Chakshushya, which pacifies Vata-pitta and sheeta virya, Balya (strengthening properties) ${ }^{7}$. Ghruta possesses sanskaranuvartanata properties means when it is made into any formulation it retains its properties and also accepts the properties of other drug ${ }^{8}$. Here shatavari and ghruta both have Chakshushya and vata-pittahara properties showed symptomatically better results in redness of eyes and eye irritation as compared to Eranda taila. Erand taila having vata hara properties and guru, Snigdha in nature showed better result in headache ${ }^{9}$.

According to the pathophysiology of CVS, the lipid layer of the tear film gets disturbed. Due to disturbed lipid layer, Tear Film Break up Time reduces remarkably. This disturbed tear film leads to dryness in the eye. Lipophilic action of Shatavari ghruta and Eranda 
taila strengthens the lipid layer of the tear film. It increases Tear Film Break up Time and reduces Dryness. Both Shatavari ghruta and Erand taila have lubricating properties which are very useful in reducing symptoms of Computer Vision Display Terminal Syndrome (VDTS).

\section{CONCLUSION}

Computers, smartphones, and short screen gadgets are now an integral part of our day-to-day life. Computer and other short screen gadgets are like heat factories, so excessive use of them increases Vata- pitta dosha in the eyes leading to symptoms of VDTS. As per Ayurveda classics, Shatavari ghruta and Eranda taila have properties as Snigdha (oleation property), Guru, thus pacifying the vata dosha. Lipophilic action of Shatavari ghruta and Eranda taila, strengthens the lipid layer of the tear film by it increases Tear Film Break up Time. Both have lubricating properties which are very useful in reducing dryness. Chakushya property of Shatavari Ghurta and Erand taila strengthens ocular muscles. It results in the development of pupillary reflex and a good convergence mechanism. Because of this, the patient gets relief from eye fatigue $\&$ headache. Because of these properties Shatavari Ghurta and Erand taila have a significant effect on all the parameters in VDTS.

\section{REFERENCES}

1. J K S Parihar, Vaibhav Kumar Jain et al, Computer and Visual Display Terminals (VDT) Vision Syndrome (CVDTS), Med J Armed Forces India, 2016 Jul;72(3):270-6.

2. Sushruta Samhita Uttartantra of Acharya Sushruta, Kaviraj Ambika Dutta Shastri, Chaukhambha Publications, Varanasi, Chaukhambha Publications, pg. 100, Sloka no. 18/64-65.

3. Rhett M. Schiffman, Gordon Jacobsen, Reliability and Validity of the Ocular Surface Disease Index, Arch Ophthalmol. 2000; 118(5):615-621.

4. Basic Ophthalmology, Renu Jogi, The Health Sciences Publisher, New Delhi, Fifth Edition, pg. 114.

5. Comprehensive Compendium of Supraclavicular Disorders in Ayurveda, Dr Atul Bhardwaj, ABC Press, New Delhi, 2015, 184.
6. Bhavaprakasha Nighantu of Acharya Bhava Mishra, with Hindi commentary by Prof. K.C. Chunekar, Chaukhambha Bharati Academy, Varanasi, Reprint edition, 2013, Guduchyadi Varga, pg. 378, Sloka no. 184-188.

7. Bhavaprakasha Nighantu of Acharya Bhava Mishra, with Hindi commentary by Prof. K.C. Chunekar, Chaukhambha Bharati Academy, Varanasi, Reprint edition, 2013, Ghruta Varga, pg. 750, Sloka no. 1-6.

8. Charaka Samhita of Agnivesha, Vidyotini Hindi Commentary by Pt. Kashinath Shastri and Dr Goroka Natha Chaturvedi, Chaukhambha Bharti Academy, Varanasi, Reprint edition, 2011,pg. 257, sloka no. 13.

9. Bhavaprakasha Nighantu of Acharya Bhava Mishra, with Hindi commentary by Prof. K.C. Chunekar, Chaukhambha Bharati Academy, Varanasi, Reprint edition, 2013, Taila Varga, pg. 765, Sloka no. 22-24.

\section{Source of Support: Nil \\ Conflict of Interest: None Declared}

How to cite this URL: Vijay Dubey \& S.S. Salvi: Comparative Study Of Efficacy of Shatavari Ghruta Anjana And Eranda Taila Anjana In The Management Of Visual Display Terminal Syndrome. International Ayurvedic Medical Journal \{online\} 2021 \{cited September 2021\} Available from: http://www.iami.in/posts/images/upload/1958_1965.pdf 